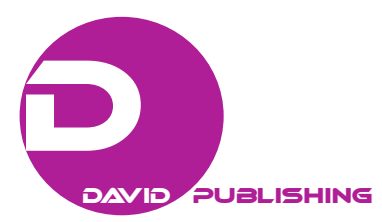

\title{
Bioeconomy in the Agrarian Resources Potential System of Ukraine
}

\author{
Elena Koval \\ National University of Life and Environmental Sciences of Ukraine, Nules, Ukraine
}

\begin{abstract}
The main goal of this research is to determine the importance and prospects of bioeconomy development in agriculture of Ukraine for international economic integration. Actual reason for this research is military occupation of west regions and the macroeconomic instability. Available resources form supply potential for agrarian production, renewable energy, and sustainable development. However, unemployment of labour, land, and capital determine the inflationary gap, which could be closed in two main ways: The innovative economic growth in business and households' sectors in accordance to bio-based principles and rational government state regulation with fiscal and monetary policies instruments. The external and internal effects of bioeconomy development in the agrarian resources system are determined in accordance to strengths, weaknesses, opportunities, and threats (SWOT)-analysis. European integration requires entrepreneurial initiative, environmental protection, social benefits in the satisfaction of individual needs of the population, modern principles of competition, such as mutual beneficial cooperation and new market creation for food security and human resources development.
\end{abstract}

Keywords: biocluster, innovation, renewable energy, resources potential, resources, employment, spatial development

\section{Introduction}

The main indicators of socio-economic development of Ukraine in 2017: Consumer price index was $113.7 \%$, industrial production price index was $116.5 \%$, index of agricultural production was $97.3 \%$, average monthly real wages per employee rate was $119.1 \%$ (compared to the prior-year period), and the level of employment rate was 57\% (State Statistic Service of Ukraine, 2017). So, it is necessary to find and expand modern bioeconomy technologies in agriculture to ensure food security and preserve the environment for sustainable economic development, social reproduction, an economic growth in the specific features of the national economy.

There is a potential for bioeconomy development in Ukraine. The population of Ukraine at the beginning of 2018 amounted to 42.4 million people, including $31 \%$ of rural population. The official unemployment rate in rural areas is $8.5 \%$. Young and middle-age people try to move to towns as urban or international migrants. Thus, there are some national and global society's threats caused by unemployment: demographic ageing, poverty, disease, crime, which must to be safeguarded by governance. Nevertheless, the agrarian sector of economy

Elena Koval, Ph.D. in Economics, associate professor, Faculty of Agricultural Management, Head of the Educational and Scientific Laboratory of Economic Theory and Bioeconomy, National University of Life and Environmental Sciences of Ukraine, Nules, Ukraine.

Correspondence concerning this article should be addressed to Elena Koval, Faculty of Agricultural Management, Heroiv Oborony St. 11, Educational Building 10, Room 114, Kyiv 03041, Ukraine. 
produced more than $13 \%$ of gross added value, provided crops and cattle, export earnings of agricultural and provision production above 17 billion USD or more than $40 \%$. So, further agrarian reform must expand agricultural production and employment in rural areas.

\section{Literature Review}

To improve a quality of life, to prevent conservation as well as responsible use of soil, water, air, energy and bioversity, support environmentally friendly development and the protection of living environments in urban and rural areas, ensure sustainable production in particular of safe and high quality food and renewable resources scientists develop tools for energy space planning (Stöglehner, Erker, \& Neugebauer, 2013).

Organization of Economic Co-operation and Development (OECD) notes the advantages of knowledge-based capital (KBC) for the relocation of resources to innovation-based growth aiming to move up the global value chain. Knowledge based assets include employee skills, organizational know-how, database, design, brands, and various forms of intellectual property (Andrews \& Criscuolo, 2013). So, a biobased business requires new features of national economic policy.

New industrial techniques are critical to successful exploitation of biowaste for high value chemicals. Scientists have an opportunity to select strains of micro-organisms that catalyse reaction of choice on one hand. Companies are already investing in facilities to exploit waste streams for chemical production on the other hand. The universities could "bridge" the gap between laboratory research and commercial application (Gronnow \& Smallwood, 2013). For instance, an international center for innovation in the circular bioeconomy is BioVale - an innovation cluster, which connects knowledge base and industry, makes new interactions across sectors for biobased supply chains, closes gaps in access to new skills, and increases national or international awareness of the region's bioeconomy innovation (Smallwood, 2017).

Experience of co-operation demonstrates that cooperative employment directly concerns 250 million people in the world. Business sector in agriculture of Ukraine consists of business partnerships, private enterprises, co-operatives, private farms, state enterprises, and other types of business but total amount of agriculture production employees are only 600,000 persons. Taking into consideration the historical experience of co-operation in Ukraine and abroad, there are different types of co-operation regarding rural areas: production, consumption, service, and credit unions. The main objectives of co-operatives are: the purchase of agricultural machinery and tools, fertilizers, seeds, and other means of production; marketing of those products that are produced for sale as a commodity; cheap credit for productive purposes (Chayanov, 1919). This integrated approach spread co-operation in the areas of production, exchange, and consumption increases the efficiency of agricultural resources reproduction.

Significant potential for job creation in rural non-farm economic activities create township and village enterprises (TVEs), which played a catalytic role in transforming the Chinese economy from a command economy to a market economy. TVEs absorbed rural surplus labour released from farming, contributed to rural economic growth, increased rural incomes, generated fiscal revenues for local governments, and helped narrow the rural-urban gap and stimulated competition with state-owned-enterprises (SOEs) and drove the process of marketization in the entire economy (Chen, 2016).

\section{Research Methods}

Bioclusters operate on the intersection of two scientific fields: sustainability transitions from a fossil-based 
economy to a bioeconomy and a subfield of economic geography called evolutionary economic geography. The multi-level perspective is used to explain how local knowledge and innovations spread from the micro levels to the higher macro levels in society (Hermans, 2018). In accordance with external and internal determinants of bioeconomy innovation spread strengths, weaknesses, opportunities, and threats (SWOT)-analysis was carried out. The main features of bioeconomy influence on resources potential system in Ukraine are shown in Figure 1.

Statistical grouping of rural household by size and land area shows the growing trend of technical support, availability of farm facilities, concentration of cattle production, intensification of measure, such as mineral and organic fertilization, crop rotation, veterinary inspection, sanitary quality control. The macroeconomic approach and Keynesian theory substantiate the important influence of the private savings and investment on the national income formation with the multiplier effect. So, it is necessary to plan general spatial organization of rural areas development in accordance with the European standards of wellbeing.

Logical approach, analyses and synthesis, scientific abstraction and comparative analysis of the energy strategy of Ukraine and the countries of the European Union allows finding better ways to use available resources for energy potential from the renewable sources. In this case, there is an intersection of bioeconomy and Solow growth model.

\section{Research Results}

Decent rural employment is incorporated in the Food and Agriculture Organization (FAO) of the United Nations Strategic Planning because of next challenges: ageing of agricultural labors in agriculture, poor availability of skilled labor, or skills not matching rural labor market needs, insufficient labor supply at peak times, particularly in agriculture (e.g., for weeding, harvesting), low labor productivity, income push out the youth, educated labor from agriculture, and natural resources becoming degraded. In particular, land, fisheries, and water, and growing competition for their use, labor constrains challenges for the upgrading from subsistence farming into commercial agriculture. FAO's comparative advantage of "green jobs" are full and productive employment and decent work, implemented skills development methodologies, a corporate-approach on climate-smart agriculture for protecting and conserving the environment, adapting to climate change, reducing greenhouse gas emissions (Fang, 2016).

It should be noted the supply of land reducing as a result of the country's temporary occupation of Crimea and the area of anti-terrorist operations in the Donbass, according to official sources is 44,000 square kilometres or $7.3 \%$ of the country. However, the agricultural lands are 42.7 million hectares, of which arable land-31.5 million hectares. As a result of reforms all agricultural lands were divided into private and state ownership of $75 \%$ and $25 \%$, respectively. In recent years, large-scale agriculture enterprises work in agribusiness with more than 100,000 hectares of farmland, which combine production stage, processing, logistics, and trade. Therefore, monopoly tendencies are observed on factor and output markets.

For instance, scientific estimates based on models corresponding to the production-theoretic approach consisting of three simultaneous equations for the translog production function, the first-order condition, and a supply function indicate that firms in the Ukrainian dairy industry tend to exercise oligopsony market power because the relevant indicators, the estimated parameter of market power, and the Lerner Index, are mostly significantly different from zero (Perekhozhuk et al., 2016). 


\begin{tabular}{|c|c|}
\hline $\begin{array}{l}\text { Strengths } \\
\text { Available resources determine the productive capacity } \\
\text { of the country to ensure economic and food security. } \\
\text { Comparative advantages in the world trade. } \\
\text { The national economic policy opens the perspectives } \\
\text { for international cooperation in agriculture and energy. } \\
\text { Agrarian gross value added and export potential } \\
\text { increase. } \\
\text { Intellectual, creative, administrative potential of people } \\
\text { is developed for welfare growth in rural areas. }\end{array}$ & $\begin{array}{l}\text { Weaknesses } \\
\text { The war in the east causes the militarization of budget } \\
\text { expenditures and destructs the economic ties. } \\
\text { High interest rate and low rent income limits profits and the } \\
\text { innovation involvement. } \\
\text { Inflation processes arise as a result of total output decrease. } \\
\text { Seasonal unemployment of resources, technological } \\
\text { replacement of labor with capital encourages migration } \\
\text { highly skilled professionals and workers abroad. } \\
\text { Low factors income level causes transfers payments with the } \\
\text { crowding out effect. }\end{array}$ \\
\hline $\begin{array}{l}\text { Opportunities } \\
\text { Small enterprises and households association establish } \\
\text { the balance of interbranch profitability level, capital } \\
\text { accumulation and relocation. } \\
\text { Additional jobs and income of the population } \\
\text { guarantees social protection and full employment GDP. } \\
\text { The concentration of capital broadens the innovation } \\
\text { potential for social and industrial infrastructure. } \\
\text { Higher level of resources productivity in the agrarian } \\
\text { sector expands production possibility of the economy. } \\
\text { Cooperation and diversification expand the assortment } \\
\text { of agrarian products and services. }\end{array}$ & $\begin{array}{l}\text { Threats } \\
\text { Global climate change defines resource-saving technologies } \\
\text { and forms of business diversification; } \\
\text { Dependence on world market conditions, which are } \\
\text { correlated with the currencies exchange, causes previously } \\
\text { the raw material component of the national export and } \\
\text { sensitivity to world cycles. } \\
\text { Bankruptcies of small enterprises in conditions of agrarian } \\
\text { markets monopolization by large-scale causes the lower real } \\
\text { income and welfare with social tension and deterioration of } \\
\text { the criminal situation, the lack of ideological benchmarks on } \\
\text { universal values, high morals. }\end{array}$ \\
\hline
\end{tabular}

Figure 1. SWOT analysis of bioeconomy influence on resources potential system. Source: Own elaboration.

Solow growth model determines an economy rate of saving, the size of its capital stocks and efficiency, technologies, labor productivity as more effective sources of economic growth. At the Golden Rule level of capital, the marginal product of capital net of depreciation must be equal zero. This condition is used for the economic policy with the higher level of consumption. Nevertheless, fixed assets in agriculture decrease and must be renewal. The structure and the efficiency of the total resource potential of the sector, as well as directions of strategic planning and forecasting could be improved for sustainable growth.

World experiences argue that clustering in the agricultural sector presents many benefits. It creates environment for the establishment of interfirm, cooperation, works as a system that facilitate the diffusion of innovations (both technical and organizational) and is a means to channel public support to increase the competitiveness of the agricultural and agro-industrial sectors in a given territory (Eva Gálvez-Nogales, 2010). Relationships between European Union and Ukraine are determined with comparative advantage in the production of unprocessed products (wheat, corn, sunflowers, rapeseeds, sunflower, and rapeseeds oil). The comparative advantages of bio-energy sources are rather high (Zhemoyda \& Kvasha, 2014)

Clusters are seen as being particularly beneficial for rural households, farmers, small- and medium- sized agribusiness. It allows them to achieve scale economies and share costs related to training, info sharing, certification, and technology application. It let improve agricultural labor productivity, rural employment, labor potential, and culture to increase well-being of people.

\section{Analyses}

Bioeconomy research and innovation policy in EU is setting course for a resource-efficient and sustainable 
economy. The European Commission in 2014 has set a Bioeconomy Strategy and action plan which focuses on three key aspects: developing new technologies and processes for the bioeconomy; developing markets and competitiveness in bioeconomy sectors; pushing policymakers and stakeholders to work more closely together (European Commission, 2014). To achieve these we made a comparative analysis of the Energy Strategy of Ukraine (2017) and EU Energy Security Strategy (2014). It showed that the main objectives are increasing energy security, increasing energy efficiency levels, and reducing anthropogenic impact. But the ways of achieving the goals are different.

In April 2016, Deputy Minister for European Integration V. Rutytska and Deputy Minister of Agriculture and Rural Development of Poland E. Lech signed a protocol of the 4th meeting of the Ukraine-Polish working group on cooperation in agriculture among the topical issues of bilateral cooperation, involving innovative technologies in agriculture and common researches as the basis of sustainable and innovative development of agricultural production (see http://minagro.gov.ua/en/node/21292).

In 2017, National University of Life and Environmental Sciences of Ukraine organized Educational and Scientific Laboratory of Economic theory and bioeconomy for the future researches in establishing the main trends and patterns of state regulation improvement and support for the effective use of resources in the agricultural sector. In particular influence of bioeconomy on spatial development of territories, Bioeconomy Strategy of Ukraine Formation, developing cluster policy to connect relation between knowledge base and agriculture, industry, ecology, and education (Talavyria, Koval, \& Dobrivs'ka, 2017). Developing and implementing the Bioeconomy Strategy of Ukraine acquires special relevance from February 24, 2018 when Ukraine became a member of the International Renewable Energy Agency (IRENA).

\section{Conclusions}

In accordance with the multi-level perspectives, there were external effects of bioeconomy development in the agrarian resource system determined, such as full employment of labor, land and capital, agrarian market and infrastructure improvement, additional financing and investment, local budget fulfilling, higher national and international competitiveness on factor and output markets, gross value added increase and trade balance surplus, export potential forming, corporate social responsibility, inflationary gap decrease, better level of well-being for people, and shift from a fossil-based economy to a bioeconomy with less pressure on environment. The internal effects for the agrarian entrepreneurs and households will be in labor productivity increase, profits and investment for innovation opportunities expansion, resources allocation and effectiveness improvement, and perspective forms of business organization in regional rural development in the European integration process.

So, the basic principles of agrarian resources reproduction with bioeconomy are denominated: the need of economic security; whole economic system integrity; government control in socio-economic development; balance of economic structure; strengthening of national awareness. In this case, the role of bioeconomy in the agrarian resources potential system of Ukraine is to provide the rational reproduction of productive forces. Thus, bioeconomy technologies improve the efficient use of intellectual, creative, and labor potential with employment and productivity of agrarian resources increase. As a result, agrarian markets will be expanding with export potential. Bioeconomy innovations will enable to ensure biodiversity and environmental protection, which is very important for European integration. 


\section{References}

Andrews, D., \& Criscuolo, C. (2013). Knowledge based capital, innovation and resource allocation. Retrieved from http://www.oecd.org/officialdocuments/publicdisplaydocumentpdf/?cote=ECO/WKP(2013)38\&docLanguage=En

Chayanov, A. (1991). The theory of peasant co-operatives. Great Britain: Ohio State University Press Columbus.

Chen, H. (2016). Township and village enterprises. Retrieved from http://www.oxfordbibliographies.com/view/document/ obo-9780199920082/obo-9780199920082-0128.xml

European Commission. (2014). Research and innovation. Retrieved from http://ec.europa.eu/research/bioeconomy/index. cfm?pg=policy

European Union. (2014). European Union Energy Strategy. Retrieved from http://europa.eu/pol/ener/index_en.htm

European Union. (2017). Energy strategy of Ukraine until 2035. Retrieved from http://zakon4.rada.gov.ua/laws/show/605-2017 -\%D1\%80/paran6\#n6

Fang, C. (2016, June). Rural labor in transition: Structural change, migration and governance. Proceeding from IAMO Forum 2016, Halle (Saale), Germany.

Gálvez-Nogales, E. (2010). Agro-based clusters in developing countries: Staying competitive in a globalized economy. Retrieved from http://www.fao.org/docrep/012/i1560e/i1560e.pdf

Gronnow, M. J., \& Smallwood, M. (2013). Biowastes: A new feedstock for the chemicals industry. Retrieved from https://www.researchgate.net/publication/260391395_Biowastes_a_new_feedstock_for_the_chemicals_industry

Herman, F. (2018). The potential contribution of transition theory to the analysis of bioclusters and their role in the transition to a bioeconomy. Biofuels, bioproducts and Biorefining, 12, 265-276. doi: 10.1002/bbb

Perekhozhuk, O., Glauben, T., Grings, M., \& Teuber, R. (2016). Approaches and methods for the econometric analysis of market power: A survey and empirical comparison. Retrieved from https:/www.researchgate.net/publication/294278916_ Approaches_and_methods_for_the_econometric_analysis_of_market_power_A_survey_and_empirical_comparison

Smallwood, M. (2017, October). Proceeding from IFIB-2017. Italian Forum on Industrial Biotechnology and Bioeconomy 2017, Roma, Italy.

State Statistic Service of Ukraine. (2017). Macroeconomic indicators. Retrieved from http://www.ukrstat.gov.ua/

Stöglehner, G., Erker, S., \& Neugebauer, G. (2013). Tools for energy spatial planning: A guide for the selection and application of planning process. Retrieved from http://www.oerok.gv.at/fileadmin/Bilder/2.Reiter-Raum_u._Region/1. OEREK/OEREK_2011/\%C3\%96REK_PS_Publikationen/Tools_Energieraumplanung_BMLFUW.pdf

Talavyria, M., E. Koval, E., \& Dobrivs'ka, M. (2017). Bioenergy potential development in Ukraine. Retrieved from http://knau.kharkov.ua/visn_econom_201703_229.html

Zhemoyda, O., \& Kvasha, S. (2014). A new challenge for Ukraine: Is regional leadership on agri-food and bioenergy markets possible? Retrieved from https://www.researchgate.net/profile/Sergii_Kvasha 